University of Nebraska - Lincoln

DigitalCommons@University of Nebraska - Lincoln

$6-2000$

\title{
Parasite Community Structure in Pimephales promelas (Pisces: Cyprinidae) from Two Converging Streams
}

\author{
M. A. Weichman \\ University of Nebraska - Lincoln \\ John A. Janovy Jr. \\ University of Nebraska - Lincoln, jjanovy1@unl.edu
}

Follow this and additional works at: https://digitalcommons.unl.edu/bioscijanovy

Part of the Parasitology Commons

Weichman, M. A. and Janovy, John A. Jr., "Parasite Community Structure in Pimephales promelas (Pisces: Cyprinidae) from Two Converging Streams" (2000). John Janovy Publications. 8.

https://digitalcommons.unl.edu/bioscijanovy/8

This Article is brought to you for free and open access by the Papers in the Biological Sciences at DigitalCommons@University of Nebraska - Lincoln. It has been accepted for inclusion in John Janovy Publications by an authorized administrator of DigitalCommons@University of Nebraska - Lincoln. 
J. Parasitol., 86(3), 2000, p. 654-656 (C) American Society of Parasitologists 2000

\section{Parasite Community Structure in Pimephales promelas (Pisces: Cyprinidae) from Two Converging Streams}

\section{A. Weichman and J. Janovy Jr., School of Biological Sciences, University of Nebraska Lincoln, Lincoln, Nebraska 68588-0118}

ABSTRACT: Parasites of the fathead minnow, Pimephales promelas, were examined in fish collected from Elk Creek $\left(40.88534^{\circ} \mathrm{N}\right.$, $\left.96.83366^{\circ} \mathrm{W}\right)$ and West Oak Creek $\left(40.90821^{\circ} \mathrm{N}, 96.81432^{\circ} \mathrm{W}\right)$, Lancaster County, Nebraska. These 2 streams are part of the Salt Valley watershed and flow together approximately $2 \mathrm{~km}$ downstream from the collection sites to form Oak Creek. This study examined the extent to which the 2 tributaries constitute a continuous habitat with respect to fish hosts. The parasite community included Trichodina sp., Myxobolus sp., Dactylogyrus simplex, D. bychowskyi, and D. pectenatus (all on gills); Gyrodactylus hoffmani (gill and body surface); Posthodiplostomum sp. (neascus, body cavity); and Uvulifer ambloplitis (encysted in skin). Among 46 fish from Elk Creek and 56 fish from West Oak Creek taken on 5 dates during April-July 1998, U. ambloplitis was found in Elk Creek fish at prevalences of $44-100 \%$ but in only 2 West Oak fish on 1 date. Prevalence and mean abundance of $D$. simplex also differed between the 2 sites. On the basis of these observations, fish populations in the 2 streams were considered to be distinct, with little or no fish movement between the tributaries.

Fish parasite communities in a watershed should vary depending on the extent to which tributaries constitute continuous or discrete habitats. Although streams may eventually converge, surrounding geography and land use may create distinct conditions so that plant and animal communities are characteristic of particular tributaries (Brouder and Hoffnagle, 1997). In the case of fish parasites, prevalences and abundances in these tributaries should vary according to environmental conditions, parasite life cycles, and presence of intermediate hosts (LeBrun et al., 1990; Janovy et al., 1997). In a watershed, fish movement potentially affects the distribution and abundance of parasites in the system. This study attempted to test the above ideas by using parasites to indicate whether 2 tributaries of Oak Creek, Lancaster County, Nebraska, were continuous or distinct habitats with respect to the distribution of Pimephales promelas Rafinesque, 1820 , the fathead minnow. If the tributaries differed ecologically, then they should provide separate parasite transmission opportunities. If fish movement was restricted, differences in the tributaries' parasite communities could reveal the ecological distinctions, but if fish moved freely throughout the watershed, the parasite communities in the 2 tributaries should be indistinguishable because of host mixing.

The 2 tributaries studied were Elk Creek and West Oak Creek, northwest of Lincoln, Lancaster County, Nebraska (Fig.
1). The streams are part of the Salt Valley Watershed and converge within $2 \mathrm{~km}$ of the study sites, forming Oak Creek. Elk Creek is much more sinuous than West Oak Creek, has steeper banks, and is fairly heavily wooded with trees and brush along much of its length. West Oak Creek passes through farmland and, for about $0.5 \mathrm{~km}$ on either side of the study site, the banks are treeless. Pimephales promelas were collected from Elk Creek $\left(40.88534^{\circ} \mathrm{N}, 96.83366^{\circ} \mathrm{W}\right)$ and West Oak Creek $\left(40.90821^{\circ} \mathrm{N}, 96.81432^{\circ} \mathrm{W}\right)$ from April to October 1998. Collection dates (sample size) are Elk Creek: 13 April (9), 20 April (11), 20 May (3), 7 June (11), 9 July (12); West Oak Creek: 6 April (8), 20 April (7), 20 May (11), 7 June (15), 9 July (15). Fish were taken to the laboratory alive and dissected within 72 hr. Parasites were identified and nomenclatural decisions were justified using Mizelle (1937a, 1937b), Price (1938), Mizelle and Donahue (1944), Hoffman (1967), and Mayes (1976, 1977). Videotapes were made and digital images were captured

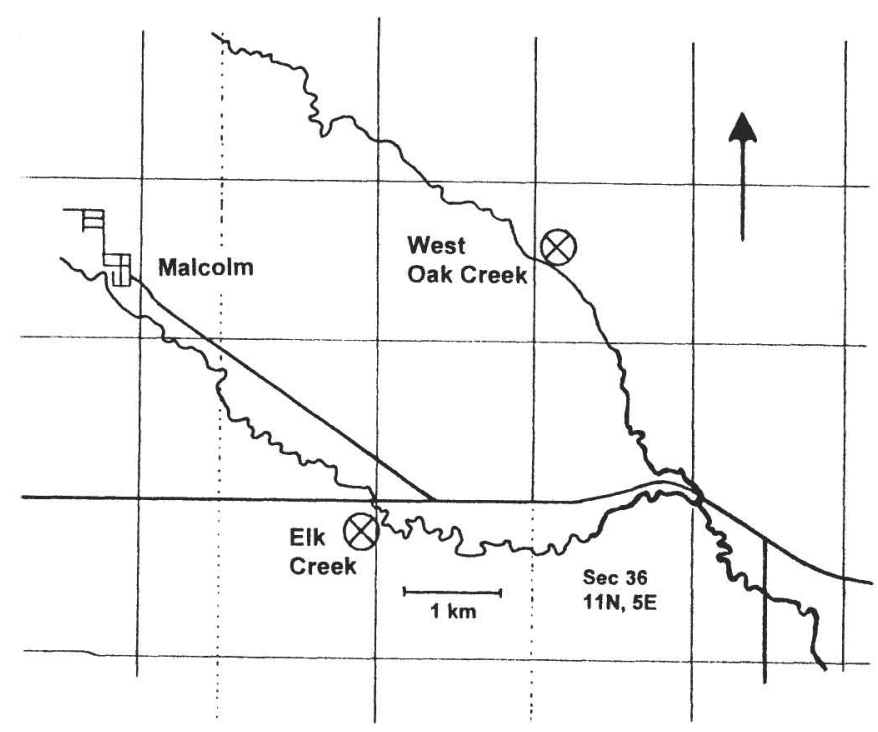

FIGURE 1. Collection sites west of Lincoln, Lancaster County, Nebraska. 

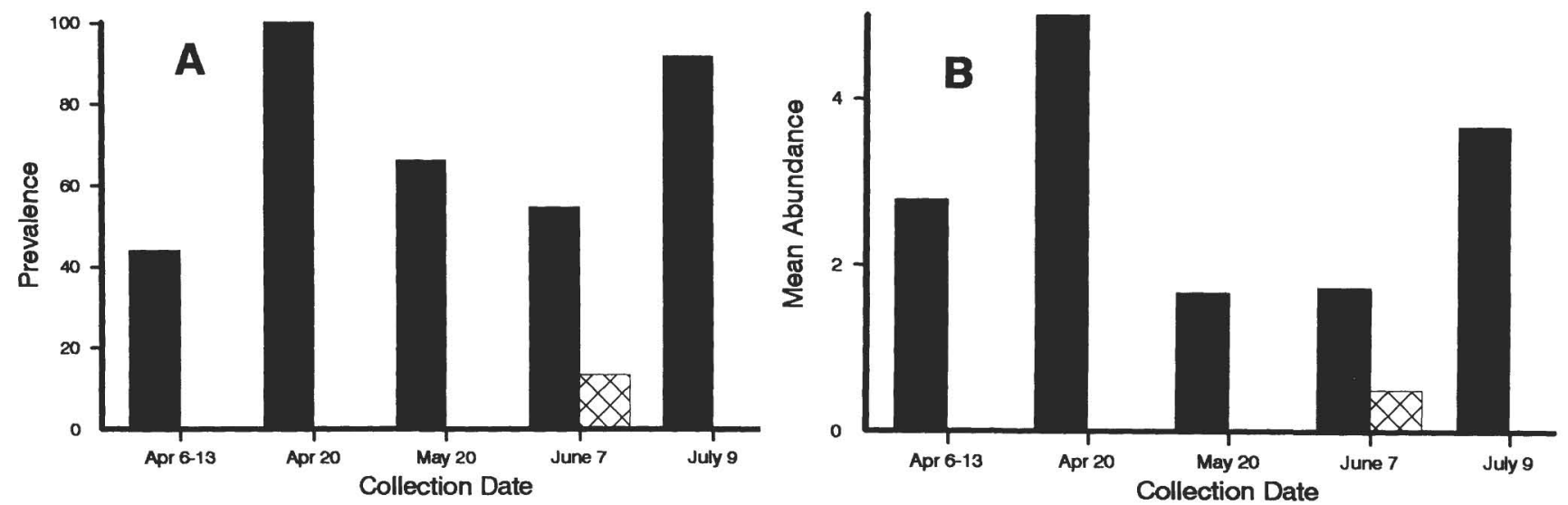

FIGURE 2. Prevalence (A) and mean abundance (B) of Uvulifer ambloplitis in fathead minnows at 2 collecting sites. Solid bars, Elk Creek; crosshatched bars, West Oak Creek.

at $\times 40$ and $\times 100$ of both haptor and male reproductive system sclerotized parts for all Monogenea whenever possible.

Significance of differences in prevalence at the 2 sites was determined with $2 \times 2$ contingency tables for each collection date; mean abundance differences were tested for significance by Student's $t$-tests on both unranked and ranked variates, Mann-Whitney $U$-tests, 1-way ANOVAs on both ranked and unranked variates, and Kruskal-Wallace tests, all with $\alpha=0.05$. Terminology is consistent with that recommended by Bush et al. (1997).

Hosts ranged from 3.7 to $6.3 \mathrm{~cm}$ long; 1-way ANOVA revealed no significant differences in fish size among dates at West Oak Creek $\left(F_{4,52}=2.495\right)$, but at Elk Creek, the fish did vary significantly in size, with a mean of $4.97 \mathrm{~cm}$ in April to $5.83 \mathrm{~cm}$ in July $\left(F_{4,41}=7.417\right)$. West Oak Creek fish were smaller than Elk Creek fish on 4 of the 5 collection dates and significantly so on the last two dates $(t=2.35,24$ df for 7 June; $t=6.17,25 \mathrm{df}$ for 9 July). At West Oak Creek, the collection included 20 males, 26 females, and 10 that could not be sexed. At Elk Creek, the collection included 21 males, 18 females, and 7 that could not be sexed. The parasite community included Trichodina sp. (Ciliophora: Peritrichia), Myxobolus sp. (Myxozoa: Myxosporea), Dactylogyrus simplex Mizelle, 1937, D. bychowskyi Mizelle, 1937, and D. pectenatus Mayes, 1977 (all on gills); Gyrodactylus hoffmani Welborn and Rogers, 1967 (gill and body surface); Posthodiplostomum sp. (neascus, body cavity); and Uvulifer ambloplitis Hughes, 1927 (encysted in skin). These parasites exhibit a variety of characteristic life cycles and transmission mechanisms (Janovy et al., 1997).

Uvulifer ambloplitis was found in Elk Creek fish at prevalences of $44-100 \%$ and mean abundances (variances) of 1.7 (4.3) -5.1 (15.9) but in only 2 West Oak fish on 1 date (Fig. 2). Prevalences were not independent of collection site on all dates. Mean abundance of $U$. ambloplitis did not vary significantly among collection dates at Elk Creek, but mean abundances varied significantly between sites on all dates. Prevalences and mean abundances of gill Dactylogyrus spp. increased throughout the study, with both values being higher in West Oak than in Elk Creek (Figs. 3, 4). Prevalence of $D$. simplex was independent of site on the third and fifth collection dates, but not on the others. Prevalences of both $D$. pectenatus and $D$. bychowskyi were independent of site on all collection dates. The null hypothesis of no difference in mean abundance was rejected using all 3 analysis methods for all 3 Dactylogyrus spp. within collection site. Body cavity neascus from Elk Creek fish
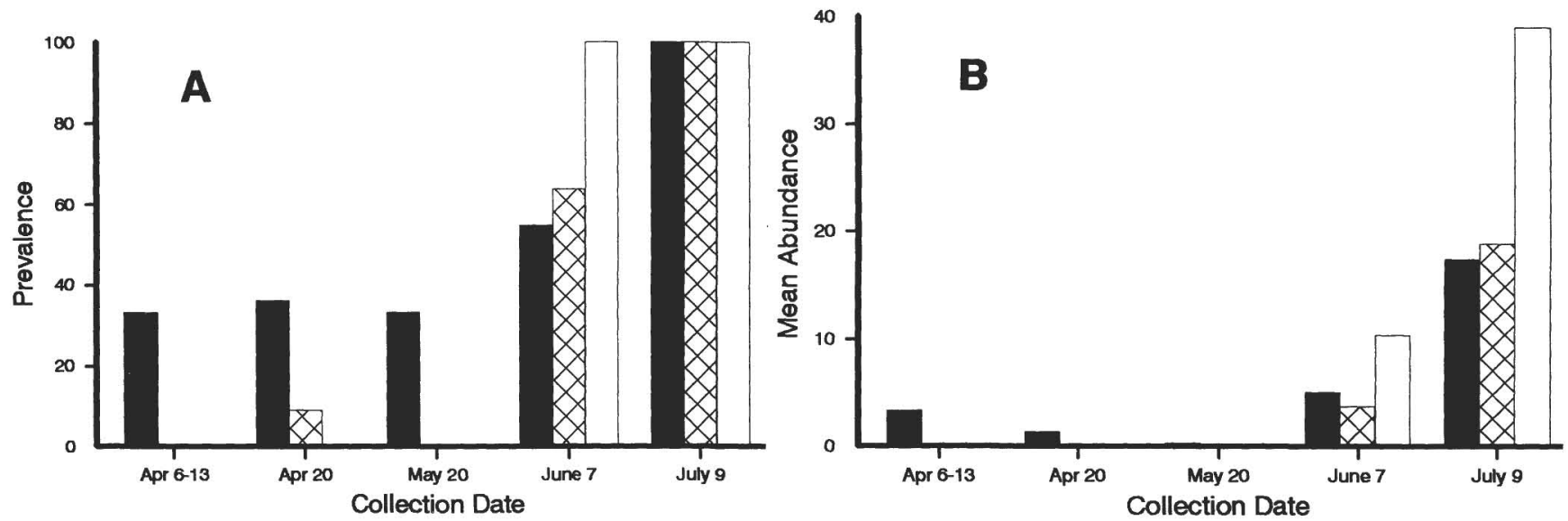

Figure 3. Prevalences (A) and mean abundances (B) of 3 Dactylogyrus species in fathead minnows collected at Elk Creek, Lancaster County, Nebraska. Solid bars, D. simplex; crosshatched bars, D. pectenatus; open bars, D. bychowskyi. 

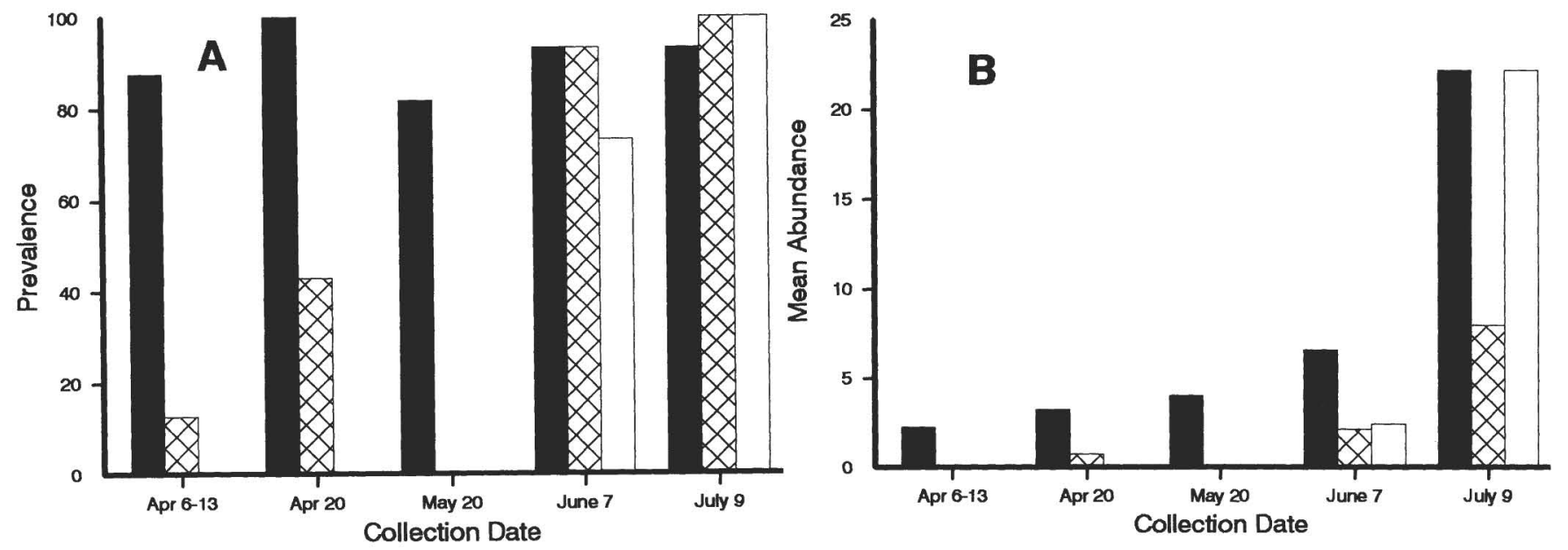

Figure 4. Prevalences (A) and mean abundances (B) of 3 Dactylogyrus species in fathead minnows collected at West Oak Creek, Lancaster County, Nebraska. Solid bars, D. simplex; crosshatched bars, D. pectenatus; open bars, D. bychowskyi.

had higher prevalences and densities on all collection dates, but these differences were significant only in the July sample.

Differences in prevalence and mean abundance of $U$. ambloplitis are biologically significant; thus, one can draw important conclusions about the degree of host isolation in the tributaries. Evidently, $P$. promelas did not move extensively throughout the watershed during the study period; if they did, the Elk Creek and West Oak Creek populations would be mixed and statistical differences in parasite prevalence and abundance should not be observed. The presence of $U$. ambloplitis in only 1 tributary also suggests that snail fauna differs in Elk and West Oak creeks. Helisoma spp. are intermediate hosts for $U$. ambloplitis; obviously the snails are present in Elk Creek, but it is not known whether they might also be present in some parts of West Oak Creek or whether land use differences, for example agricultural runoff, affected snail fauna in West Oak Creek. However, Physa sp. was present in the latter tributary. Differences in definitive host (kingfisher) use of the respective habitats could also explain the observations. Differences in the dynamics of Dactylogyrus spp. populations also suggest that fish in the 2 tributaries constitute separate populations. For example, in early collections, prevalences of $D$. simplex were higher in West Oak Creek than in Elk Creek, although these differences are not as striking as in the case of $U$. ambloplitis. In summary, although the sample sizes are relatively small, the study nevertheless demonstrates that parasites can be used as markers to reveal certain aspects of fish ecology and behavior in this particular system. However, it remains to be determined whether the dynamics of other, co-occurring fish species' parasite communities are the same as those of $P$. promelas or whether fathead minnows move more extensively throughout the Oak Creek watershed during other parts of the year.
This work was supported by a Howard Hughes Medical Institute scholarship to M.A.W.

\section{LITERATURE CITED}

Brouder, M. J., AND T. L. Hoffnagle. 1997. Distribution and prevalence of the Asian fish tapeworm, Bothriocephalus acheilognathi, in the Colorado River and tributaries, Grand Canyon, Arizona, including two new host records. Journal of the Helminthological Society of Washington 64: 219-226.

Bush, A. O., K. D. Lafferty, J. M. Lotz, and A. W. Shostak. 1997. Parasitology meets ecology on its own terms: Margolis et al. revisited. Journal of Parasitology 83: 575-583.

Hoffman, G. L. 1967. Parasites of North American freshwater fishes. University of California Press, Berkeley, California. 486 p.

JANOVY, J. JR., S. D. SNYDER, AND R. E. Clopton. 1997. Evolutionary constraints on population structure: The parasites of Fundulus zebrinus (Pisces: Cyprinodontidae) in the South Platte River of Nebraska. Journal of Parasitology 83: 584-592.

LeBrun, N., F. Renaud, AND A. Lambert. 1990. Differential settlement by Diplozoon gracile (Monogenea) on teleostean (cyprinid) hosts in relation to biological and environmental conditions. Acta Ecologica 11: 729-739.

MAYES, M. A. 1976. The adult platyhelminth parasites of Nebraska fishes. Ph.D. Dissertation. University of Nebraska, Lincoln, Nebraska.

-. 1977. New species of Gyrodactylus and Dactylogyrus (Trematoda: Monogenea) from fishes of Nebraska. Journal of Parasitology 63: 805-809.

MizeLLE, J. D. 1937a. Ectoparasites of the blunt-nosed minnow ( $\mathrm{Hy}$ borhynchus notatus). American Midland Naturalist 18: 612-621.

- 1937b. Notes on ectoparasitic trematodes of fishes. Transactions of the Illinois State Academy of Science 30: 311-312.

, AND M. A. Donahue. 1944. Studies on monogenetic trematodes XI. Dactylogyridae from Algonquin Park fishes. American Midland Naturalist 31: 600-624.

PRICE, E. W. 1938. A new species of Dactylogyrus (Monogenea: Dactylogyridae), with the proposal of a new genus. Proceedings of the Helminthological Society of Washington 5: 48-49. 